
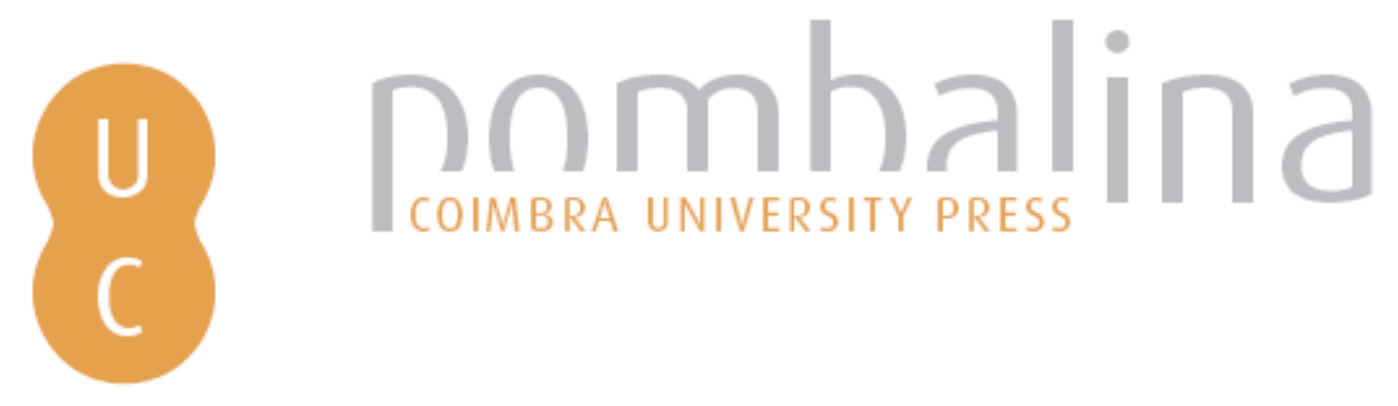

\title{
The tooth as an alternative matrix in forensic toxicology: application to the determination of benzodiazepines
}

\author{
Autor(es): $\quad$ Quintela, O.; Mon, M.; Blanco, P.; Castro, A. de; Lopez-Rivadulla, M.; \\ Cruz, A. \\ Publicado por: Imprensa da Universidade de Coimbra; International Academy of Legal \\ URL \\ persistente: \\ Medicine \\ DOI: \\ URI:http://hdl.handle.net/10316.2/31827 \\ Accessed : $\quad$ 26-Apr-2023 15:46:27
}

A navegação consulta e descarregamento dos títulos inseridos nas Bibliotecas Digitais UC Digitalis, UC Pombalina e UC Impactum, pressupõem a aceitação plena e sem reservas dos Termos e Condições de Uso destas Bibliotecas Digitais, disponíveis em https://digitalis.uc.pt/pt-pt/termos.

Conforme exposto nos referidos Termos e Condições de Uso, o descarregamento de títulos de acesso restrito requer uma licença válida de autorização devendo o utilizador aceder ao(s) documento(s) a partir de um endereço de IP da instituição detentora da supramencionada licença.

Ao utilizador é apenas permitido o descarregamento para uso pessoal, pelo que o emprego do(s) título(s) descarregado(s) para outro fim, designadamente comercial, carece de autorização do respetivo autor ou editor da obra.

Na medida em que todas as obras da UC Digitalis se encontram protegidas pelo Código do Direito de Autor e Direitos Conexos e demais legislação aplicável, toda a cópia, parcial ou total, deste documento, nos casos em que é legalmente admitida, deverá conter ou fazer-se acompanhar por este aviso.

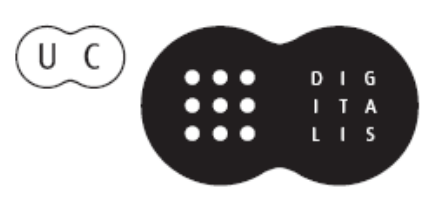




\section{Duarte Nuno Vieira Anthony Busuttil \\ Denis Cusack • Philip Beth}
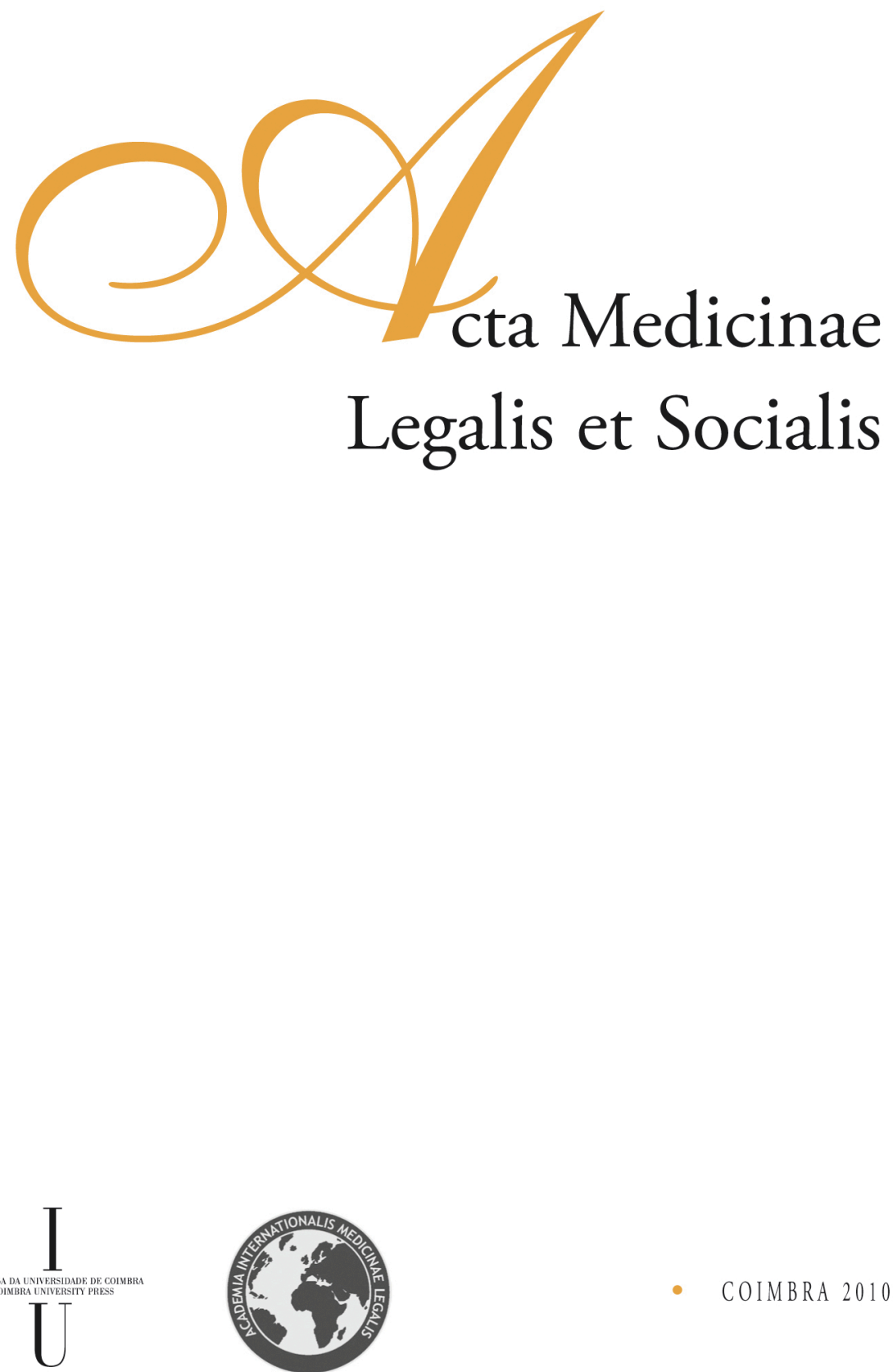
O. Quintela, M. Mon, P. Blanco, A. de Castro, M. Lopez-Rivadulla, A. Cruz

Service of Forensic Toxicology, Institute of Legal Medicine, University of Santiago de Compostela, Spain

\title{
THE TOOTH AS AN ALTERNATIVE MATRIX IN FORENSIC TOXICOLOGY. APPLICATION TO THE DETERMINATION OF BENZODIAZEPINES
}

\begin{abstract}
Toxicological investigation of drugs in dentin can help in reconstructive identification of corpses with extensive soft tissues destruction. In this work the analysis of benzodiazepines in dental tissues was performed by LC/MS/MS. The method allows the identification and quantitation of 16 benzodiazepines, after a solid phase extraction procedure. The method was applied to 16 teeth real cases from patients under chronic treatment with these drugs. Twelve out of these cases tested positive to any benzodiazepine, while 4 were negative. This means that a positive result confirms the use of the drug, but a negative one does not exclude it.
\end{abstract}

\section{Introduction}

When studying unidentified, putrefied or skeletonised human remains, it may be difficult to obtain information on drug habits which may prove important for the construction of a biological profile [1], in the context of a reconstructive identification process. Dentin is a hard dental tissue that in vital teeth is in contact with the blood that irrigates the dental pulp and, therefore, the chemicals presents in blood can reach the dentin. But it is also a tissue with a slow metabolic turnover, meaning that the incorporation of chemicals into the dentin probably takes place at a slow rate. Therefore teeth should be evaluated as an alternative biological matrix in the investigation of chronic exposure to chemicals. Although hair is usually the matrix of choice for this purpose [2], in some forensic cases it may have disappeared (extensive destruction of soft tissue in burned corpses and, in general, in the cases where identification of the human remains is done by forensic dentistry techniques). In these circumstances, and due to the extraordinary hardness of dental tissues, teeth can be the only available biological matrix and an invaluable source of data from a toxicological point of view.

\section{Material and Methods}

Apparatus. The HPLC system was a Waters Alliance 2795 Separation Module with a Waters Alliance series column heater/cooler (Waters, Mildford, MA, USA). For the 
chromatographic separation, an Atlantis ${ }^{\circledR} \mathrm{T} 33 \mu \mathrm{m}(2,1 \times 100 \mathrm{~mm})$ (Waters, Mildford, USA) was employed, using $2 \mathrm{mM}$ ammonium formate buffer $\mathrm{pH} 3$ and acetonitrile as mobile phase at a flow rate of $0.2 \mathrm{~mL} / \mathrm{min}$ (gradient mode). The column temperature was kept at $26^{\circ} \mathrm{C}$. The total run time was $17 \mathrm{~min}$.

For the detection, a tandem mass spectrometer Quattro Micro ${ }^{\mathrm{TM}}$ API ESCI (Waters, Mildford, USA) with a triple quadrupole was employed. The instrument was operated in electrospray in the positive ionization mode $(\mathrm{ESI}+)$. Nitrogen was used as nebulization and desolvation gas at a flow rate of $500 \mathrm{~L} / \mathrm{h}$, heated to $450^{\circ} \mathrm{C}$, and as cone gas at a flow of $50 \mathrm{~L} / \mathrm{h}$. Capillary voltage and source block temperature were $3 \mathrm{kV}$ and $140^{\circ} \mathrm{C}$, respectively.

Chemicals, reagents and standard solutions. Alprazolam, Oxazepam, Lorazepam, Tetrazepam, Clorazepam, Bromazepam, Zolpidem, Midazolam, Diazepam, -OHAlprazolam, Triazolam, Lormetazepam, Nordiazepam, Flunitrazepam (FNZ), Zopiclone and 7-amino-FNZ, Zolpidem-d6, FNZ-d7, Alprazolam-d6, Oxazepam-d6, -OHAlprazolam-d5, 7-amino-FNZ-d7 y Diazepam-d5 were obtained from Cerilliant ( $L G C$ Standards Barcelona, Spain). All reagents of analytical grade were obtained from Merck (Darmstadt, Germany). A stock standard solution for each compound was prepared at $10 \mu \mathrm{g} / \mathrm{mL}$ in methanol. Working solutions were prepared by appropriate dilution of these stock standards in methanol.

Teeth samples. Drug-free teeth samples were obtained from healthy donors from a public hospital and a private dental clinic. Teeth from patients under benzodiazepine treatment were obtained from the Special Patients Unit of the Dentistry Faculty (Santiago de Compostela, Spain).

Sample preparation and extraction. Teeth were first shredded in a crushing device consisted of two aluminum plates and a hydraulic press. Teeth fragments were then pulverized in a ball mill (Precellys 24), and intact enamel fragments were discarded. $300 \mathrm{mg}$ of the pulverized dentin were transferred into a vial and $5 \mathrm{~mL}$ of borate buffer $\mathrm{pH} 9$ added. After overnight incubation, the buffer was filtered and submitted to solid phase extraction (OASIS HLB 3cc, Waters). The eluate was then evaporated to dryness and reconstituted with $60 \mu \mathrm{L}$ of mobile phase. Finally, $40 \mu \mathrm{L}$ were injected into the HPLC system.

\section{Results and discussion}

The method was validated for 16 benzodiazepines, achieving limits of detection from 0,1 to $5 \mathrm{ng} / \mathrm{g}$. Although full validation was not performed, selectivity, linearity, precision and accuracy (interday and intraday) were under the acceptable analytical criteria $[3,4]$. The analysis of blank teeth samples showed the absence of any trace of interfering peaks from endogenous compounds at the corresponding retention times of each analyte. Representative chromatogram of a real sample is shown in Figure 1.

The method was applied to 16 real samples, obtained from patients under chronic treatment (lasting from 1,5 to 15 years) with benzodiazepines. Results are shown in Table 1. In four cases any BZD was detected, and in the remaining 12 cases concentrations were highly variable $(0.168-352 \mathrm{ng} / \mathrm{g})$. In 11 out of the 16 cases, the identified benzodiazepine was the one prescribed to the patient. Alprazolam was the 
most prevalent substance, detected in 7 out of 16 cases, which could mean this analyte has a higher affinity for the dental tissues. In case \#1, besides the parent drug, some metabolites were detected. In eight samples, the active substance identified was different to the one referred in the anamnesis, maybe due to the failure of the anamnesis in identifying all the benzodiazepines taken by the patient.

In four cases the analysis was negative, even after 8,10 or 15 years of treatment. This could be due to the lack of vitality of the tooth when the benzodiazepine treatment was prescribed. In these cases, blood supply to the dental pulp is eliminated, so any drug can reach the dental tissues. Vital conditions of the teeth were not known when the treatment was established. Under these results, dental tissues are suitable to identify chronic exposure to drugs. Nevertheless, although a positive result confirm the use of the substance, a negative result does not exclude it.

Other authors also identified drugs in dental tissues, such as opiates and cocaine $[1,5]$, and found similar results. Under their opinion, the presence of drugs in dental tissues is difficult to interpret, but can help in the identification process of human remains. Pascual et al [6] also used dental tissues to quantify the environmental exposure of children to tobacco smoke, being able to identify nicotine and cotinine in deciduos teeth.

\section{Conclusions}

Dental tissues can be used in toxicological analysis when other common matrices are not available. The identification of benzodiazepines in teeth confirms the treatment with these drugs. This can help in a reconstructive identification process in those cases where forensic odontology techniques have to be used.

\section{References}

Cattaneo C., Gigli F., Lodi F., Grande M. The detection of morphine and codeine in human teeth:An aid in the identificacion and estudio de human skeletanl remains. The Journal of Forensic Odontostomatology. 21: 1-5, 2003.

Health and Human Services. Food and Drug Administration. Guidance for Industry. Bioanalytical Method Validation. 2001. http://www.fda.gov/cder/guidance/index.htm.

Pascual J.,Diaz A. A simple and reliable method for the determination of nicotine and cotinine in teeth by gas chromatography/mass spectrometry. Rapid Communications In Mass Spectrometry, 17: 2853-55, 2003.

Pellegrini M., Casá A., Marchei E., Pacifici R., Mayne R., Barbero V.,et al. Developement and validation of a gas chromatography-mass spectrometry assay for opiates and cocaine in human teeth. Journal of Pharmaceutical and Biomedical Análisis 40: 662-68, 2006,

Shah V.P., Midha K.K., Findlay J.W., Hill H.M., Hulse J.D., McGilveray I.J.et al. Bioanalytical method validation-A revisit with a decade of progress. Pharm. Res. 17: 1551-1557, 2000.

Villain M, Cirimele V, Kintz P. Hair analysis in toxicology. Forensic Sci. Int. 142 :127-134, 2004. 


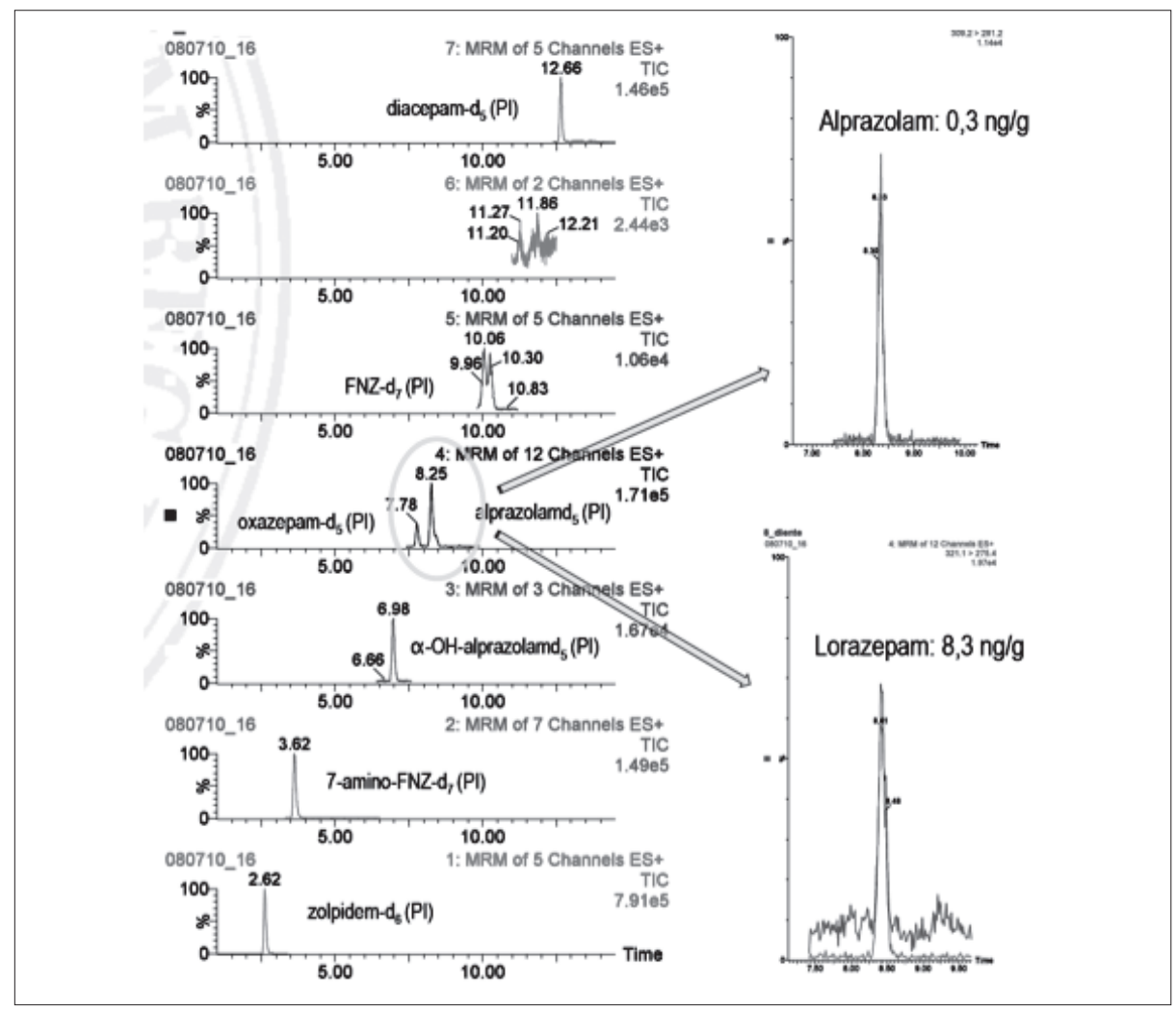

Figure 1 - Chromatogram of a real case showing alprazolam and lorazepam in dental tissues.

\begin{tabular}{|c|c|c|c|c|}
\hline \multicolumn{3}{|c|}{ Anamnesis Information } & \multicolumn{2}{|c|}{ Toxicological Results } \\
\hline $\begin{array}{l}\text { CASE } \\
\mathrm{N}^{\circ}\end{array}$ & PRESCRIBED BZD & $\begin{array}{l}\text { TREATMENT } \\
\text { PERIOD }\end{array}$ & $\begin{array}{l}\text { IDENTIFIED } \\
\text { BDZ }\end{array}$ & $\begin{array}{c}\text { CONCENTRATION } \\
\mathrm{ng} / \mathrm{g}\end{array}$ \\
\hline 1 & $\begin{array}{l}\text { Clorazepate } \\
\text { Dipotassium }\end{array}$ & 3 years & $\begin{array}{c}\text { Oxacepam } \\
\text { Nordiazepam } \\
\text { Diazepam }\end{array}$ & $\begin{array}{c}5.14 \\
352.34 \\
\text { Traces }\end{array}$ \\
\hline 2 & $\begin{array}{l}\text { Clorazepate } \\
\text { Dipotassium }\end{array}$ & 5 years & Diazepam & Traces \\
\hline 3 & Ketazolam & Not Known & $\begin{array}{c}\text { Oxacepam } \\
\text { Lorazepam } \\
\text { Nordiazepam }\end{array}$ & $\begin{array}{c}14.81 \\
171.12 \\
4.62\end{array}$ \\
\hline 4 & Bromaz/Lormetazepam & 1.5 years & $\begin{array}{c}\text { Lormetazepam } \\
\text { Diazepam }\end{array}$ & $\begin{array}{l}1.46 \\
0.96\end{array}$ \\
\hline 5 & Lorazepam & 3 years & $\begin{array}{l}\text { Midazolam } \\
\text { Lorazepam }\end{array}$ & $\begin{array}{l}1.26 \\
4.14\end{array}$ \\
\hline 6 & Diazepam & 10 years & N/D & N/D \\
\hline 7 & Bromazepam & 15 years & N/D & N/D \\
\hline 8 & Alprazolam & 3 years & $\begin{array}{l}\text { Alprazolam } \\
\text { Lorazepam }\end{array}$ & $\begin{array}{l}0.36 \\
8.35\end{array}$ \\
\hline 9 & Alprazolam & 3 years & Alprazolam & 1.05 \\
\hline 10 & Alprazolam & 5 years & Alprazolam & 2.80 \\
\hline 11 & Alprazolam & 7 years & Alprazolam & 5.64 \\
\hline 12 & Alprazolam & 8 years & $\begin{array}{c}\text { Alprazolam } \\
\text { Nordiazepam }\end{array}$ & $\begin{array}{c}0.46 \\
77.88\end{array}$ \\
\hline 13 & Alprazolam & 8 years & Alprazolam & 0.16 \\
\hline 14 & Alprazolam & 8 years & $\begin{array}{l}\text { Alprazolam } \\
\text { Nordiazepam }\end{array}$ & $\begin{array}{c}5.30 \\
19.53\end{array}$ \\
\hline 15 & Bromazepam & 15 years & N/D & N/D \\
\hline 16 & Alprazolam & 8 years & N/D & N/D \\
\hline
\end{tabular}

(N/D = Not Detected $)$

Table 1 - Results of the analysis of the real cases. 